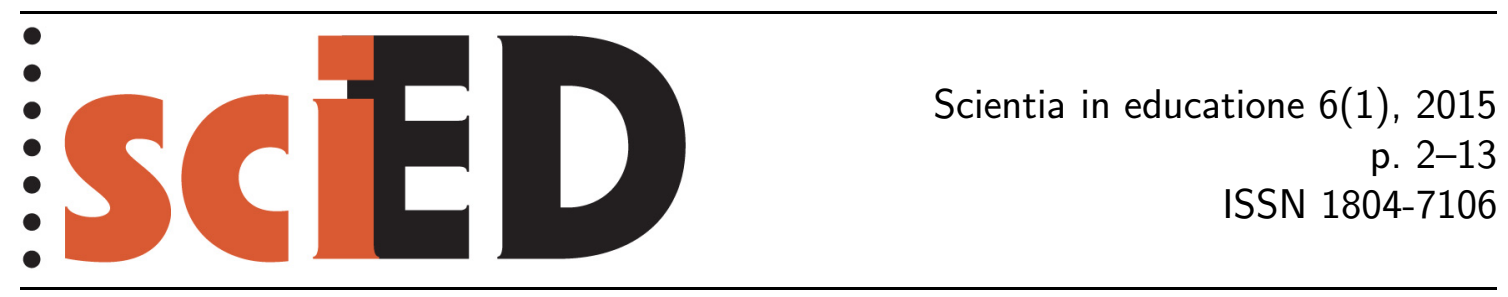

\title{
Záujem žiakov nižšieho sekundárneho vzdelávania o biologické vedy
}

\author{
Jana Fančovičová, Milan Kubiatko
}

\begin{abstract}
Abstrakt
Záujem žiakov o prírodovedné predmety celosvetovo klesá a žiaci ako dôvody nezáujmu uvádzajú náročnost' a nedôležitost daných predmetov pre ich život a budúce povolanie. Cielom výskumného šetrenia bolo zistit, aká oblast z prírodovedných predmetov žiakov zaujíma najviac, a tiež vplyv premenných ako sú gender a vek na záujem o biologické vedy (predpokladali sme, že žiaci prejavia najväčší záujem o biologické vedy). Výskumu sa zúčastnilo 389 žiakov nižšieho sekundárneho vzdelávania vo veku 10-15 rokov. Každý respondent mal na čistý hárok papiera uviest lubovolný počet spontánnych otázok - mal napísat otázky, ktorých odpoved’ ho zaujíma. Viac ako $91 \%$ všetkých otázok predstavovali otázky z biológie a nie z fyziky alebo chémie. Väčší záujem o biológiu bol zistený u dievčat. Z oblasti biológie bolo najviac otázok položených v šiestom ročníku a najmenej v piatom ročníku, čo je pravdepodobne spôsobené obsahom kurikula. Tento jav je vysvetlený v záverečnej kapitole článku.
\end{abstract}

Klíčová slova: biologické vedy, gender, spontánne otázky, žiaci nižšieho sekundárneho vzdelávania.

\section{Lower Secondary School Pupils' Interest in Biological Sciences}

\begin{abstract}
Pupils' interest in science subjects has been decreasing all around the world; the reasons lying in the perceived difficulty and unimportance of science subjects for pupils' future life and work. The aim of the research was to specify which field of science subjects is the most interesting for pupils and to find out the influence of variables such as gender and age on the interest in biological sciences (we supposed that pupils would be mostly interested in biology). The sample size was 389 lower secondary school pupils of age between 10 and 15 . Each respondent was to write any number of spontaneous questions on a blank sheet of paper - they were to write questions whose answers were of interest to them. The highest number of questions was from biology $(91 \%)$, not from chemistry or physics. The girls were more interested in biology, the $6^{\text {th }}$ graders wrote the highest number of questions and the lowest number of questions was written by the $5^{\text {th }}$ graders. This situation is probably caused by curriculum; the reasons are explained in the conclusions.
\end{abstract}

Key words: biological sciences, gender, spontaneous questions, lower secondary school pupils. 
Záujem o prírodovedné predmety je klesajúci nielen v lokálnom, ale aj vo svetovom meradle. Prečo tomu tak je, je otázkou a aj dôvodom výskumu mnohých odborníkov a záujemcov o danú oblaste. Z výsledkov ich prác je evidentné, že jedným z častých dôvodov nezáujmu je absencia významu prírodovedných predmetov u žiakov základných škôl. Ak žiaci nevidia význam daného predmetu, tak o uvedený predmet nemajú ani záujem. Cielom štúdie bolo zistit, aká oblast' z prírodovedných predmetov žiakov zaujíma. Na základe zistených odpovedí žiakov je potom možné navrhnút implikácie do pedagogickej praxe, ktoré môžu byt učitelmi využité, a viest̉ k zvýšeniu záujmu o danú skupinu predmetov.

\section{TEORETICKÉ VÝCHODISKÁ}

Záujem hrá významnú úlohu v každodennom živote ludí, ale tiež v ich profesionálnej oblasti. V rámci vzdelávacieho procesu ovplyvňuje samotný proces vyučovania, učenia a tiež aj výsledky žiakov (Krapp, 1999). Záujem ako pojem sa definuje ako vztah osoby k určitej situácii, objektu či správaniu iných jedincov (Lewin, 1951; Nuttin, 1984). Záujem je charakterizovaný afektívnou a kognitívnou zložkou, pričom zväčša vyvoláva reakcie uberajúce sa pozitívnym smerom. V tomto prípade si však nemožno zamieňat pojem záujem s pojmom radost' (z anglického „enjoyment“). Záujem tiež zahŕňa schopnost́ angažovat sa s pozorovaným vysokým úsilím do úloh, ktoré patria do záujmu jedinca (Rathunde, 1993). Definície pojmu záujem možno nájsţ aj v lokálnych zdrojoch, ked’ Ríčan (2010) chápe záujmy ako zvláštny druh motívov a definuje ich ako potrebu, ktorá sa uspokojuje vykonávaním určitej činnosti.

Záujem žiakov o prírodovedné predmety celosvetovo klesá (Ramsden, 1998), čo potvrdzujú nielen zahraničné, ale aj domáce výskumy. Prírodovedné predmety sú aj nad’alej žiakmi považované za nezaujímavé a vzdialené od každodenného života. Na nezáujem žiakov základných škôl o prírodovedné predmety upozorňuje už v roku 1999 Veselský, pričom podobná situácia je aj v roku 2009 (Veselský \& Hrubišková, 2009). Rovnako Sláviková, Igaz \& Adam (2012) poukazujú na neoblúbenost́ a nezáujem žiakov o biológiu ako prírodovedný predmet. Klesajúci záujem o biológiu potvrdili i autori Prokop \& Komorníková (2007), Prokop, Prokop \& Tunnicliffe (2007). K podobným zisteniam dospeli i autori Veselský (2010), Pavelková, Škaloudová \& Hrabal (2010), zaoberajúci sa záujmom žiakov o chémiu ktorí potvrdili súvis nízkeho záujmu o predmet chémia s jej náročnostou a nedostatočným chápaním významu tohto predmetu v živote jednotlivca. Záujem o fyziku ako d’alší z prírodovedných predmetov je na nízkej úrovni (Dopita \& Grecmanová, 2008; Mandíková, 2009). Mnoho výskumov týkajúcich sa postojov žiakov k prírodovedným predmetom poukazuje na fakt, že o biológiu majú žiaci najväčší záujem v porovnaní s inými prírodovednými predmetmi, ako fyzika a chémia (Osborne, Simon \& Collins, 2003). Podobne ako výskumné zistenia zo Slovenska a Čiiech, tak aj v medzinárodné štúdie uvádzajú nezáujem o prírodovedné predmety. Žiaci ako dôvody nezáujmu uvádzajú náročnost' a nedôležitost prírodovedných predmetov pre ich život a budúce povolanie. S narastajúcim vekom záujem o prírodovedné predmety u žiakov klesá, pričom väčší záujem o ne majú chlapci v porovnaní s dievčatami. Žiaci považujú prírodovedné predmety za zložité, nesúvisiace s praktickým životom (Ramsden, 1998). Najväčší pokles záujmu o prírodovedné predmety je počas prestupu žiakov zo základnej školy na strednú školu, preto by sa mala tomuto obdobiu venovat väčšia pozornost́ (Skamp \& Logan, 2005). Záujem žiakov o prírodovedné predmety klesá vo veku od devät do štrnást rokov (Murphy \& Beggs, 2003). 
Papanastasiou \& Papanastasiou (2004) na základe údajov z výskumu TIMSS zistovali vplyv faktorov ako socioekonomický status rodiny, budúca ašpirácia respondentov, klíma v škole, spôsob vyučovania na postoje respondentov k prírodovedným predmetom. Zistili, že najsilnejší vplyv na utváranie postojov mal spôsob vyučovania, budúca ašpirácia respondentov a klíma v škole. Respondenti, ktorí uviedli, že by sa v budúcnosti radi venovali práci, ktorá by súvisela s prírodovednými predmetmi, mali pozitívnejší postoj $\mathrm{k}$ prírodovedným predmetom ako študenti zaujímajúci sa o prácu mimo prírodovednej oblasti. V prípade, ak žiaci označili klímu v škole ako dobrú, tak aj ich postoje boli pozitívne. Jediný faktor, ktorý nepreukázal vplyv na postoje k prírodovedným predmetom, bol socioekonomický status. Autori skúmali relatívne málo preskúmavané faktory, ktoré sú vo výskumných prácach iných autorov zriedkavým javom. Awan et al. (2011) analyzovali vo svojej štúdii niekolko literárnych zdrojov, ktoré sa týkali vnímania prírodovedných predmetov. Výsledky z týchto prác dávali do širšieho kontextu, pričom niektoré z analyzovaných zdrojov vychádzali z výsledkov velkých výskumných projektov, ako sú PISA, TIMSS či ROSE. Výsledky je možné zhrnút nasledovne:

1. Žiaci z rozvojových krajín (Afrika, juhovýchodná Ázia) majú pozitívnejšie postoje k prírodovedným predmetom ako žiaci z rozvinutých krajín (Európa, Severná Amerika).

2. Žiaci mali celkovo pozitívny vztah k prírodovedným predmetom.

3. Väčšina štúdií poskytuje len všeobecné informácie o postojoch študentov k prírodovedným predmetom. Menšina z nich sa snaží zistit aj vplyv premenných na postoje, pričom najčastejšou premennou, ktorej vplyv sa zistuje, je gender. Autori, zaoberajúci sa vplyvom pohlavia, uvádzajú, že neexistuje žiaden rozdiel medzi chlapcami a dievčatami, prípadne pozitívnejšie postoje majú chlapci.

4. Žiaci z východnej Ázie majú negatívnejšie postoje k prírodovedným predmetom ako žiaci z iných krajín.

5. Ak sa hodnotili jednotlivé predmety, tak najpozitívnejšie bol hodnotený prírodopis, v porovnaní s fyzikou a chémiou (zemepis nebol braný do úvahy).

6. Počet žiakov, pre ktorých sú prírodovedné predmety zaujímavé, postupne stúpa.

7. Dievčatá majú pozitívnejšie postoje k prírodopisu, chlapci k fyzike (autori chémiu neuvádzajú).

Celkovo o prírodovedné predmety prejavujú väčší záujem chlapci v porovnaní s dievčatami. Greenfield (1996) uvádza, že na konci prvého stupňa chlapci pozitívnejšie vnímajú prírodovedné predmety v porovnaní s dievčatami. Prechodom do druhého stupňa je situácia opačná, chlapci majú pozitívnejší postoj k prírodovedným predmetom v porovnaní s dievčatami. Na pozitívnejšie vnímanie prírodovedných predmetov chlapcami poukazujú aj Jones, Howe \& Rua (2000). Vo svojom výskume sa tiež zaoberali činnostami, ktoré radšej vykonávajú chlapci a ktoré dievčatá. Chlapci označili, že radi realizujú experimenty s takými predmetmi, ako sú napríklad batérie, prípadne s rôznymi chemickými látkami. Na rozdiel od dievčat, ktoré preferujú činnosti súvisiace so starostlivostou o l’udské telo. Na základe uvedeného je možné sledovat’, prečo chlapci preferujú fyziku a chémiu a dievčatá biológiu. Van Roten (2004) potvrdil častokrát zistený fakt, ktorý vypovedá o pozitívnejšom ponímaní prírodovedných predmetov chlapcami v porovnaní s dievčatami. Podla autora sa za uvedenými výsledkami skrýva väčšia ochota chlapcov prijímat poznatky z prírodovedných disciplín. Mavrikaki et al. (2012) analyzovali relatívne často prezentovanú premennú, ktorou je navštevovaný ročník respondentov a ako uvádzajú, 
väčší záujem o biológiu je u mladších respondentov v porovnaní so staršími. Mnoho výskumov potvrdzuje, že negatívne postoje žiakov k prírodovedným predmetom do velkej miery súvisia s nedostatkom motivácie a prepojenia vedy s reálnym životom (Osborne, Simon \& Collins, 2003).

Autori uvedených zistení vo svojich štúdiách použili ako výskumný nástroj na zistovanie záujmu o prírodovedné predmety dotazníky, pričom sa zväčša jednalo o škálované dotazníky. Dotazníky obsahujú výroky zamerané na záujem respondentov o biológiu a jej jednotlivé oblasti ako zoológiu, botaniku, geológiu a biológiu človeka. V predloženom výskumnom šetrení bola však použitá metóda volných slovných asociácií (projektívne techniky či brainwriting). Uvedená metóda je známa skôr pre psychologické disciplíny. Použitie metódy volných slovných asociácií nebolo pri rešerši výskumných prác týkajúcich sa niektorého z prírodovedných predmetov zistené ako metóda výskumu. Volné slovné asociácie umožňujú zistovat nielen vedomosti, ale aj názory a postoje respondentov na určitý jav či pojem. Výskumný nástroj pozostáva z inštrukcie (znenia zadania úlohy) pre respondentov. Zadanie by malo byt čo najpresnejšie a pochopitel’né pre danú vekovú skupinu respondentov. Respondenti majú možnost volnej odpovede, čo im umožňuje vytvárat spontánne odpovede (Novák, 1989). Spontánne odpovede nie sú zamerané len na jednu z oblastí biológie, ale týkajú sa rôznych oblastí prírodovedných predmetov.

\section{Ciele, VÝSKUMnÉ OTÁZKY A HYPOTÉZY}

Hlavným cielom výskumného šetrenia bolo zistit, aká oblast’ z prírodovedných predmetov žiakov najviac zaujíma a či existuje rozdiel medzi chlapcami a dievčatami. Vychádzajúc z teórie, predpokladali sme, že žiaci položia najviac otázok z biológie a že biológia ako predmet ich bude aj najviac zaujímat́ v porovnaní s chémiou a fyzikou, preto d’alšie ciele výskumného šetrenia smerovali práve k biológii ako vyučovaciemu predmetu. Zistovali sme, či budú mat̉ väčší záujem o biológiu dievčatá alebo chlapci, či sa líši záujem o biológiu s ohladom na ročník a nakoniec, ktorá oblast' biológie zaujíma viac chlapcov a ktorá viac dievčatá.

Na základe stanovených cielov boli stanovené výskumné otázky:

1. Ktorá oblast' z prírodovedných predmetov žiakov najviac zaujíma?

2. Líši sa záujem chlapcov a dievčat o jednotlivé oblasti prírodovedných predmetov?

3. Existuje rozdiel v záujme o biológiu medzi chlapcami a dievčatami?

4. Žiaci ktorého ročníka budú mat́ najväčší záujem o biologické témy?

5. Ktorá biologická disciplína bude zaujímat viac chlapcov a ktorá dievčatá?

Na základe stanovených výskumných otázok boli zo vztahových výskumných otázok vytvorené hypotézy:

1. Žiaci budú mat̉ väčší záujem o biológiu ako o iné prírodovedné predmety.

2. Chlapci budú mat’ väčší záujem o biológiu ako dievčatá, čo sa prejaví v počte naformulovaných spontánnych otázok.

3. Mladší žiaci budú mat̉ väčšś záujem o biologické témy ako starší žiaci, ktorých záujem bude nižší.

4a. Dievčatá bude zaujímat biológia človeka viac ako chlapcov.

4b. Chlapcov bude viacej zaujímat zoológia v porovnaní s dievčatami. 


\section{MetodiKA}

Výskumu sa zúčastnilo 389 žiakov nižšieho sekundárneho vzdelávania vo veku 10-15 rokov (priemerný vek bol 12 rokov) získaných náhodným výberom. Žiaci boli z troch základných škôl, pričom každá zo škôl nemala alternatívny plán výučby, ale vyučovací proces prebiehal klasickým spôsobom v 45minútových hodinách. V tabulke 1 sú uvedené počty chlapcov a dievčat v jednotlivých ročníkoch.

Tab. 1: Počet chlapcov a dievčat v jednotlivých ročníkoch

\begin{tabular}{cccccccccc}
\hline \multicolumn{2}{c}{ 5. ročník } & \multicolumn{2}{c}{ 6. ročník } & \multicolumn{2}{c}{ 7. ročník } & \multicolumn{2}{c}{ 8. ročník } & \multicolumn{2}{c}{ 9. ročník } \\
\hline chlapci & dievčatá & chlapci & dievčatá & chlapci & dievčatá & chlapci & dievčatá & chlapci & dievčatá \\
\hline 9 & 10 & 0 & 18 & 10 & 8 & 10 & 8 & 14 & 12 \\
\hline 24 & 31 & 21 & 33 & 11 & 20 & 11 & 13 & 10 & 17 \\
\hline 8 & 12 & 1 & 9 & 10 & 5 & 9 & 12 & 8 & 7 \\
\hline
\end{tabular}

Ako metóda boli použité volné slovné asociácie, pričom každý respondent mal na čistý hárok papiera uvieste lubovolný počet spontánnych otázok - mal napísat otázky, ktorých odpoved' ho zaujíma. Respondenti na hárky uviedli školu, ktorú navštevujú, pohlavie a vek, zaujímali sme sa tiež, či čítajú vo volnom čase literatúru, ktorá ich zaujíma, či využívajú počítač a internet bud' doma alebo niekde inde. Respondentom bol poskytnutý čas zodpovedajúci dížke jednej vyučovacej hodiny. Administrácia otázok spočívala v ich zaznamenaní a následnom začlenení do príslušnej prírodovednej oblasti.

\section{VÝSLEDKY}

Celkovo bolo do analýz použitých 1310 spontánnych otázok (priemerne 3-4 otázky na žiaka). Položené otázky sa týkali rôznych oblastí života. Na základe charakteru najčastejšie položených otázok boli vytvorené hlavné kategórie - oblasti záujmu: Biológia, Vedy o Zemi, Chémia, Technológie. Každá z uvedených kategórií bola rozdelená do subkategórií. Vzhladom k tomu, že neboli zo strany žiakov uvedené žiadne otázky týkajúce sa fyziky, a len vel’mi malé množstvo otázok z chémie a technológií, tieto kategórie sme dalej nerozdelovali do subkategórí. Pozornost' sme zamerali predovšetkým na kategóriu Biológia a Vedy o Zemi. Kategória Biológia bola rozdelená do nasledovných subkategórií: Fyziológia a anatómia človeka, Anatómia živočíchov, Genetika, Etológia, Mikrobiológia a virológia, Vyhynuté organizmy, Človek a zvieratá, Botanika, Medicína, Výživa, Evolúcia, Neurológia, Iné.

Kategória Vedy o Zemi bola rozdelená do nasledovných subkategórií: Geológia, Environmentalistika, Meteorológia, Koniec sveta, Astronómia.

Z kategórie „Biológia“ sa najviac otázok týkalo oblasti fyziológie a anatómie človeka (241 otázok), d’alej z oblasti anatómie živočíchov (181 otázok) a najmenej sa žiaci zaujímali o subkategóriu „Neurológia“, na ktorú žiaci položili spolu iba 19 otázok. Subkategórie „Mikrobiológia a virológia“ a „Botanika a mykológia“ mali takmer rovnaký počet položených otázok, ktorých bolo nad 60 z každej oblasti. Najčastejšie vyskytujúcimi sa otázkami z kategórie „Biológia“ boli napríklad otázky typu: „Kol'ko kostí má ludské telo?“, „Ako vznikla vtáčia chrípka?“, „Ako vznikli baktérie?", „Čo bolo skôr - vajce alebo sliepka?", „Prečo pes šteká?", „Ako vznikla vtáčia chrípka?", „Prečo na jeseň opadávajú listy?“, „Prežil by človek, keby nastala doba ladová?". 
Tab. 2: Hodnoty multivariátnej analýzy rozptylu

\begin{tabular}{lccc}
\hline & Wilksovo lambda & F-hodnota MANOVy & $p$ (hladina významnosti) \\
\hline Gender & 0,97 & 3,32 & $<0,05$ \\
\hline Ročník & 0,86 & 4,83 & $<0,001$ \\
\hline Gender*Ročník & 0,92 & 2,50 & $<0,01$ \\
\hline
\end{tabular}
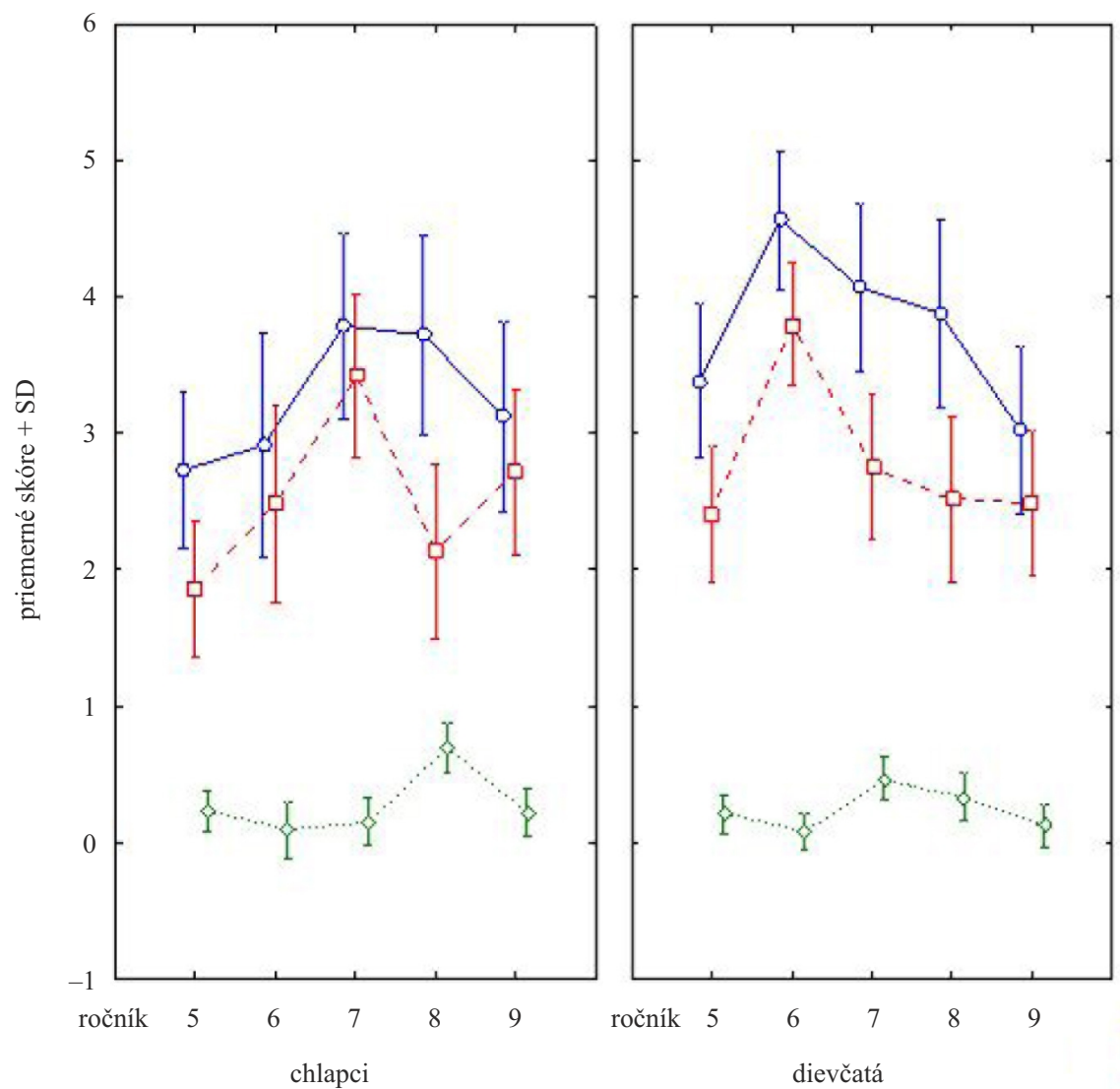

otázky celkom otázky Biológia otázky Vedy o Zemi

Graf 1: Priemerný počet otázok s ohladom na gender a ročník

Najviac otázok z kategórie „Vedy o Zemi“ sa žiaci pýtali zo subkategórie „Geológia“ (30 otázok), po nej nasledovala „Astronómia“ (26 otázok) a najmenej otázok (4) z tejto kategórie bolo položených z oblasti „Koniec Sveta“. Z tejto kategórie je možné uviest' napríklad otázky: „Prečo sa vyrábajú autá, ked’ výfuky znečistujú životné prostredie?“, „Prečo je v zime sneh?“, „Kedy nastane koniec sveta?“, „Je niekde koniec vesmíru?"

V d’alších analýzach sme zistovali, ktoré faktory vplývajú na počet položených otázok. Zaujímalo nás, ktoré oblasti zaujímajú mladších a starších žiakov. Súčty spontánnych otázok boli definované ako závislé premenné. Pohlavie, vek, ročník, čítanie, prítomnost počítača a internetu boli faktormi v multivariátnej analýze rozptylu. V tabulke 2 sú uvedené hodnoty MANOVy, pričom sú uvedené len významné rozdiely. Preto sa v d’alšej časti výsledkov venuje pozornost̉ len genderu a ročníku.

Pohlavné rozdiely a ročník mali vplyv na počet položených spontánnych otázok. Zistili sme štatisticky významný rozdiel v počte položených otázok medzi chlapcami a dievčatami celkovo a tiež v oblasti biológia (graf 1). Celkovo najviac otázok položili dievčatá rovnako ako z oblasti biológia. Najviac otázok kládli dievčatá v šiestom roč- 
níku, naopak najmenej otázok sa pýtali v deviatom ročníku. Chlapci položili najviac otázok v siedmom ročníku a najmenej v piatom ročníku. Z kategórie „Vedy o Zemi“ bol rozdiel v položených otázkach medzi chlapcami a dievčatami minimálny, pričom viac otázok položili z tejto oblasti chlapci, z čoho vyplýva, že chlapcov viac zaujímajú informácie o Zemi, astronómia, meteorológia apod. Pri vyhodnocovaní otázok z kategórie „Biológia“ boli zaznamenané pohlavné rozdiely v jednotlivých ročníkoch. Kým dievčatá kládli výrazne najviac otázok z kategórie „Biológia“ v šiestom ročníku, chlapci kládli najviac biologických otázok v siedmom ročníku. Najmenej otázok položili dievčatá aj chlapci zhodne v piatom ročníku.

Celkovo bolo najviac spontánnych otázok položených v siedmom ročníku, v dalších ročníkoch počet otázok postupne klesal. Z oblasti biológie bolo najviac otázok položených v šiestom ročníku (330), následne v siedmom (258), čo mohlo byt spôsobené obsahom učebného predmetu $\mathrm{v}$ daných ročníkoch. Obsah učiva $\mathrm{v}$ týchto ročníkoch je zameraný na biológiu človeka a jeho telo, zdravie, taktiež na stavbu tiel živých organizmov, čo dokazuje aj najvyšší počet otázok položených z oblasti fyziológie a anatómie človeka (241 otázok). Najmenej otázok z biológie položili žiaci piateho ročníka, čo je zaujímavé, nakol'ko práve žiaci piateho ročníka majú najpozitívnejšie postoje $\mathrm{k}$ predmetu biológia.

Z oblasti „Vedy o Zemi“ neboli v jednotlivých ročníkoch zistené až také velké rozdiely v počte položených otázok, avšak najviac otázok z tejto kategórie bolo položených v ôsmom ročníku (33), čo bolo pravdepodobne spôsobené tým, že práve v ôsmom ročníku je vyučovanie zamerané na Zem, geologické procesy apod. Najmenej otázok z kategórie „Vedy o Zemi“ položili žiaci v šiestom ročníku. V ostatných ročníkoch boli rozdiely nepatrné (graf 2).



otázky celkom otázky Biológia otázky Vedy o Zemi

Graf 2: Priemerný počet otázok s ohladom na ročník 
Štatisticky významný rozdiel bol zistený medzi oblastami „Vedy o Zemi“, a to $\mathrm{v}$ prospech geológie $\mathrm{u}$ ôsmakov $(p<0,001)$, taktiež v oblasti meteorológie u ôsmakov $(p<0,05)$ a astronómie u siedmakov $(p<0,05)$ (graf 3$)$.



Graf 3: Priemerný počet otázok z geologických oblastí s ohladom na ročník

Zistili sme vplyv ročníka v oblasti „Biológia“, kde bol potvrdený štatisticky významný rozdiel v počte položených otázok medzi jednotlivými ročníkmi $(p<0,001)$ vzhladom na jednotlivé oblasti. Žiaci sa pýtali najmä otázky z oblasti „Biológia človeka“ a „Zoológia“. Kým o „Biológiu človeka“ prejavili najvyšší záujem žiaci v siedmom ročníku (64 otázok), na „Zoológiu“ sa pýtali žiaci najviac v šiestom ročníku (54 otázok). Naopak najnižší záujem o zoológiu prejavili žiaci v piatom ročníku (18 otázok) a o biológiu človeka v ôsmom ročníku (25 otázok). Z oblasti „Etológia“ sme zaznamenali výrazný nárast počtu otázok v šiestom ročníku v porovnaní s ostatnými ročníkmi, kde bol počet položených otázok nižší (graf 4).

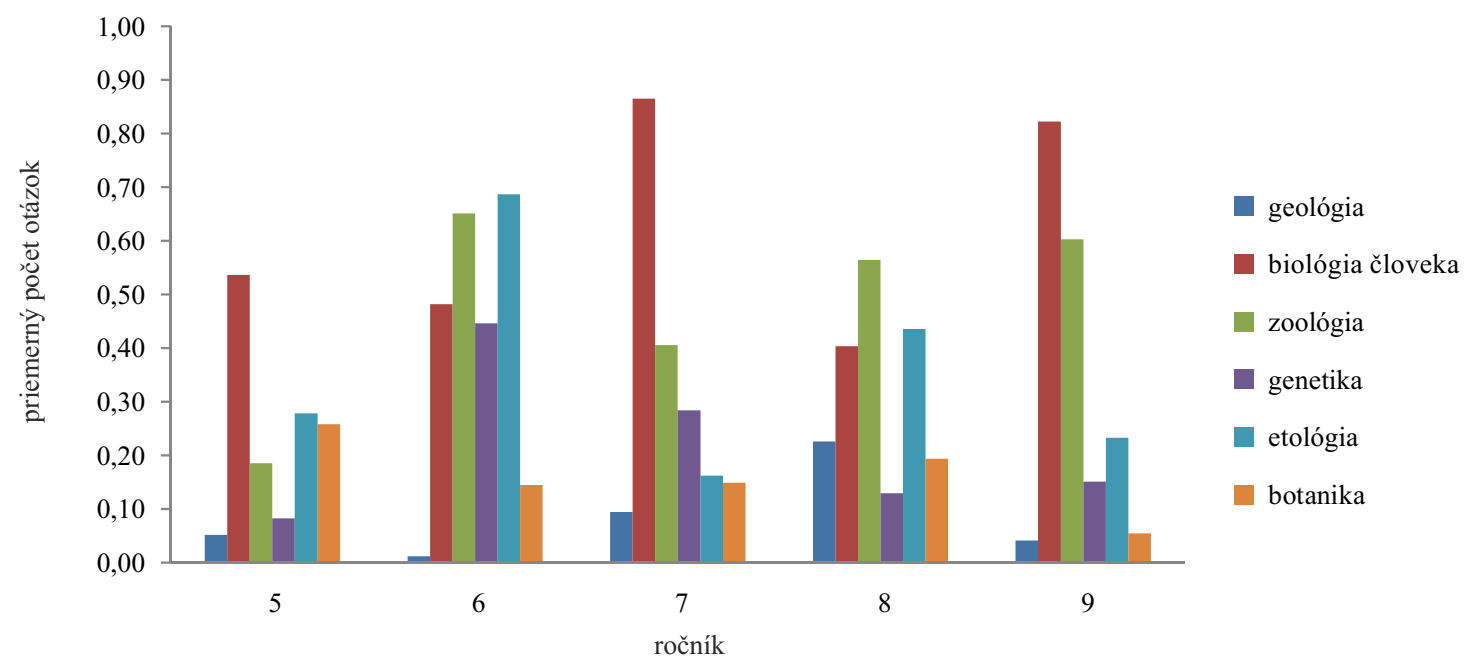

Graf 4: Priemerný počet otázok z biologických oblastí s ohladom na ročník 
Žiaci sa zaujímali nielen o oblasti, ktoré sa vyučujú, ale taktiež sa pýtali aj na otázky z iných odborov, ako je evolúcia, neurológia i medicína, ktorým sa až taká pozornost na školách nevenuje. Štatisticky významný rozdiel vo vztiahu pohlavie*ročník bol zistený pri evolúcii $(p<0,05)$ a pri neurológií $(p<0,05)$. Chlapci položili najviac otázok zameraných na evolúciu v siedmom ročníku a mali najväčší záujem o oblast’ evolúcie v šiestom ročníku a najmenej v ôsmom ročníku.

\section{Diskusia A ZÁver}

Analýzou spontánnych otázok sme zistovali, ktoré oblasti prírodovedných predmetov žiakov najviac zaujímali. Prvou hypotézou sme sa snažili overit, že žiaci budú mat väčší záujem o biológiu ako o iné prírodovedné oblasti, ktorá sa potvrdila. Viac ako $91 \%$ všetkých otázok predstavovali otázky z biológie a nie z fyziky alebo chémie, čím sa potvrdilo, že o biológiu majú žiaci najväčší záujem. K rovnakým zisteniam dospeli aj autori z Izraela, pričom respondenti položili 49,6 \% otázok z biológie (Baram-Tsabari \& Yarden, 2005). Jedným z dôvodov, prečo je o biológiu väčší záujem v porovnaní s fyzikou a chémiou, môže byt' súvislost' s obsahom daného predmetu. Ten môže byt pre žiakov zdanlivo zrozumitelnejší a konkrétnejší, ako sú fyzika a chémie. V týchto dvoch predmetoch sa vo väčšej miere preberajú veci, ktoré sú mikroskopických rozmerov a pre žiakov sú príliš abstraktné, preto aj tažko predstavitelné. V bežnom živote sa žiaci, aspoň z ich pohladu, stretávajú viac s javmi typickými pre biológiu, ked’ môžu pozorovat rastliny či živočíchy. Prípadne sledujú na sebe či na príbuzných rôzne fyziologické deje, ako je napríklad kýchanie, kašel', potenie atd'. Preto bol pravdepodobne zistený výsledok, že počet otázok týkajúcich sa biológie výrazne prevyšoval otázky z chémie a fyziky.

V druhej hypotéze bolo predpokladané, že chlapci budú mat väčší záujem o prírodovedné predmety ako dievčatá, čo sa prejaví v počte naformulovaných spontánnych otázok. Daná hypotéza sa nepotvrdila, pretože väčší záujem o túto skupinu predmetov bol zistený práve u dievčat. Dôvodom môže byt’ zistenie, že väčšina otázok sa týkala biológie, na ktorú boli viac zvedavé dievčatá v porovnaní s chlapcami, a tento jav spôsobil, že celkový počet otázok bol položený práve dievčatami. Podobne vo výskume Baram-Tsabari \& Yarden (2005) dievčatá položili celkovo 70 \% biologických otázok a chlapci dominovali vo všetkých ostatných oblastiach okrem biológie. Ako zistili aj iní autori (napr. Awan et al., 2011), biológia je dievčatami hodnotená pozitívnejšie $\mathrm{v}$ porovnaní s chlapcami. To môže súvisiet s väčším záujmom o predmety, kde dochádza k stretávaniu sa s učebným materiálom súvisiacim so životom ako takým, čo je hodnotené pozitívnejšie viac dievčatami. Na rozdiel od chlapcov, ktorí viac preferujú vedomosti z predmetov, kde sa pracuje s technikou, experimentmi atd'. Tento fakt môže byt̉ dôvodom, prečo je práve biológia pozitívnejšie hodnotená dievčatami. V podobných intenciách sa vyjadrujú aj iní autori, ako napríklad Hola (2005) či Lee \& Burkam (1996).

Tretia hypotéza verifikovala, že mladší žiaci budú mat väčší záujem o biológiu v porovnaní s dievčatami, táto hypotéza sa však nepotvrdila. Z oblasti biológie bolo najviac otázok položených $\mathrm{v}$ šiestom ročníku a následne v siedmom čo mohlo byt spôsobené obsahom učebného predmetu v daných ročníkoch. Obsah učiva v týchto ročníkoch je zameraný na biológiu človeka a jeho telo, zdravie, taktiež na stavbu tiel živých organizmov, čo dokazuje aj najvyšší počet otázok položených z oblasti fyziológie a anatómie človeka. Najmenej otázok z biológie položili žiaci piateho ročníka. Čo je zaujímavý jav, nakolko práve žiaci piateho ročníka majú najpozitívnejší postoj 
k predmetu biológia, ktorý bol dokázaný vo viacerých výskumných prácach (napr. Kubiatko, 2011; Vlčková \& Kubiatko, 2014). Prečo bol tento jav zistený? Je možné sa len domnievat na základe toho, že postoj k biológii môže byt preto pozitívny, že pre žiakov je preberaný obsah na hodinách zaujímavý, resp. výklad učitela môže byt obohatený o prvky, ktoré už vo vyšších ročníkoch pozorované nie sú. Počet otázok bol pravdepodobne preto nižší, lebo žiaci majú ešte prebratého relatívne málo učiva, preto sa ich otázky viažu výsostne na tematické okruhy, ktoré boli náplňou vyučovacích hodín biológie. Okrem biológie sa žiaci zaujímali aj o iné oblasti. Vedy o Zemi boli druhou najfrekventovanejšou oblastou, ktorá žiakov zaujímala, dalej nasledovala chémia a technológie. Vo väčšine výskumných prác, týkajúcich sa záujmu o biológiu či aj iné prírodovedné predmety, bolo zistené, že s postupujúcim vekom záujem žiakov klesá (Mavrikaki et al., 2012; Prokop, Tuncer \& Chudá, 2007). Dôvodom odlišného zistenia $\mathrm{v}$ našom výskume $\mathrm{v}$ porovnaní s inými môže byt to, že autori iných výskumných štúdií použili ako techniku dotazník so škálovanými položkami, pričom $\mathrm{v}$ našom prípade sa jednalo o iný typ zistovania záujmu (metóda volných slovných asociácií), čo môže súvisiet s odlišnými zisteniami.

Ďalšou hypotézou sme sa snažili overit, že dievčatá bude zaujímat biológia človeka viacej ako chlapcov a naopak chlapcov bude viacej zaujímat zoológia. Hypotéza však nebola potvrdená (potvrdená bola len jej prvá čast', druhá nie). Dievčatá síce mali väčší záujem o biológiu človeka v porovnaní s chlapcami, ale k podobným zisteniam sme dospeli aj v zoológii, teda väčší záujem o zoológiu mali dievčatá. Respondenti kládli najviac biologických otázok zameraných na biológiu človeka a až po nej nasledovala zoológia. K rozdielnym zisteniam dospeli aj Baram-Tsabari \& Yarden (2005), kde sa žiaci viac zaujímali o zoológiu.

Z celkových zistení vyplýva, že i ked’ sú postoje žiakov nižšieho sekundárneho vzdelávania k predmetu biológia skôr neutrálne, napriek tomu sa žiaci najviac zaujímali o biológiu v porovnaní s inými prírodovednými oblastami, ako je chémia a fyzika. Prostredníctvom spontánnych otázok sme zistili, že vedy o Zemi žiakov zaujímajú hned' po oblasti biológie. Žiakov zaujímala geológia, astronómia, environmentalistika a tiež meteorológia.

Učitel by mohol využit práve spontánne otázky a tak zistit, čo žiakov zaujíma, a v danom ročníku konkrétne tematické celky obohatit’ o poznatky, na ktoré sa žiaci dopytovali, čo môže mat́ pozitívny vplyv na postoje žiakov k biológii. Učitel' by mal žiakov motivovat a preberané učivo do istej miery prepájat s reálnym život, pretože žiakov zaujímajú otázky, ktoré sú aplikovatelné v živote. Z biológie mali žiaci najväčší záujem o oblast fyziológia a anatómia človeka a taktiež ich zaujímala zoológia. Medzi najčastejšie položené otázky patrili tie, v ktorých sa žiaci dopytovali na baktérie, zaujímali sa o vesmír, vyhynuté živočíchy apod. Učitel' môže tieto otázky využit na hodinách biológie, žiakom zadá vypracovanie projektov alebo semestrálnych prác, kde sa žiaci k odpovediam na otázky dopracujú sami.

\section{PODĚKOVÁNí}

Autori štúdie d’akujú oponentom za ich pripomienky, ktoré viedli k skvalitneniu a vyššej úrovni textu.

\section{LITERATURA}

Awan, R. U. N., Sarwar, M., Naz, A. \& Noreen, G. (2011). Attitudes toward science among school students of different nations: a revew study. Journal of College Teaching \& Learning, 8(2), 43-50. 
Baram-Tsabari, A. \& Yarden, A. (2005). Characterizing children's spontaneous interests in science and technology. International Journal of Science Education, 27(7), 803-826.

Dopita, M. \& Grecmanová, H. (2008). Středoškoláci a zájem o přrírodní vědy. e-Pedagogium, 8(4), 31-46.

Greenfield, T. A. (1996). Gender, ethnicity, science achievement and attitudes. Journal of Research in Science Teaching, 33(8), 901-933.

Hola, I. A. (2005). Uncovering gender differences in science achievement and attitudes towards science for Jordanian primary pupils. Damascus University Journal, 21(1), $19-53$.

Jones, M. G., Howe, A. \& Rua, M. J. (2000). Gender differences in students' experiences, interests, and attitudes toward science and scientists. Science Education, 84(2), 180-192.

Krapp, A. (1999). Interest, motivation and learning: An educational-psychological perspective. European Journal of Psychology of Education, 14(1), 23-40.

Kubiatko, M. (2011). Bez prírodopisu to nejde alebo ako ho vnímajú žiaci základných škôl. Studia Paedagogica, 16(2), 75-88.

Lee, V. E. \& Burkam, D. T. (1996). Gender differences in middle grade science achievement: Subject domain, ability level, and course emphasis. Science Education, 80(6), 613-650.

Lewin, K. (1951). Field theory in social science. New York: Harper \& Row.

Mandíková, D. (2009) Postoje žáků k přírodním vědám - výsledky výzkumu PISA 2006. Pedagogika, 59(4), 380-395.

Mavrikaki, E., Koumparou, H., Kyriakoudi, M., Papacharalampous, I. \& Trimandili, M. (2012). Greek secondary school students' views about biology. International Journal of Environmental \& Science Education, 7(2), 217-232.

Murphy, C. \& Beggs, J. (2003). Children's attitudes towards school science. School Science Review, 84(308), 109-116.

Novák, Z. (1989). Test volných slovných asociací jako test školních znalostí. Pedagogika, 39(4), 431-445.

Nuttin, L. (1984). Motivation, planning, and action. Leuven: University Press.

Osborne, J., Simon, S. \& Collins, S. (2003). Attitudes towards science: a review of the literature and its implications. International Journal of Science Education, 25(9), $1049-1079$.

Papanastasiou, C. \& Papanastasiou, E. C. (2004). Major influences on attitudes toward science. Educational Research and Evaluation, 10(3), 239-257.

Pavelková, I., Škaloudová, A. \& Hrabal, V. (2010). Analýza vyučovacích předmětů na základě výpovědí žáků. Pedagogika, 55(1), 38-61.

Prokop, P. \& Komorníková, M. (2007). Postoje k prírodopisu u žiakov druhého stupňa základných škôl. Pedagogika, 57(1), 37-46.

Prokop, P., Prokop, M. \& Tunnicliffe, S. D. (2007). Is biology boring? Student attitudes toward biology. Journal of Biological Education, 42(1), 36-39.

Prokop, P., Tuncer, G. \& Chudá, J. (2007). Slovakian students' attitudes toward biology. Eurasia Journal of Mathematics, Science 63 Technology Education, 3(4), 287-295. 
Ramsden, J. M. (1998). Mission impossible?: Can anything be done about attitudes to science? International Journal of Science Education, 20(2), 125-137.

Rathunde, K. (1993). The experience of interest: A theoretical and empirical look at its role in adolescent talent development. In M. Maehr \& P. Pintrich (Eds.), Advances in motivation and achievement (59-98). London: Jai Press Inc.

Ř́ičan, P. (2010). Psychologie osobnosti: obor v pohybu. Praha: Grada.

Skamp, K. \& Logan, M. (2005). Students' interest in science across the middle school years. Teaching Science, 51(4), 8-15.

Sláviková, V., Igaz, C. \& Adam, M. (2012). Postoje žiakov 8. ročníka ZŠ k predmetu Biológia 8. Biológia - Ekológia - Chémia, 16(2), 2-4.

Van Roten, F. C. (2004) Gender differences in attitudes toward science in Switzerland. Public Understanding of Science, 13(2), 191-199.

Veselský, M. (1999). Záujem žiakov o prírodovedné učebné predmety na základnej škole a hodnotenie ich dôležitosti - z pohladu žiakov 1. ročníka gymnázia. In Psychologica Zbornik Filozofickej fakulty UK, 37 (79-86). UK: Bratislava.

Veselský, M. (2010). Motivácia žiakov učit sa. Bratislava: Univerzita Komenského.

Veselský, M. \& Hrubišková, H. (2009). Zájem žáku o učební předmět chemie.

Pedagogická orientace, 19(3), 45-64.

Vlčková, J. \& Kubiatko, M. (2014). Přrírodopis v očích žáků 2. stupně základních škol. e-Pedagogium, 14(1), 20-37.

JANA FANČOVIČOVÁ, fankaj@gmail.com

Trnavská univerzita, Pedagogická fakulta

Katedra biológie

Priemyselná 4, P.O. BOX 9, 91843 Trnava, Slovenská republika

Milan KubiatKo, mkubiatko@gmail.com

Masarykova univerzita, Pedagogická fakulta

Institut výzkumu školy a zdraví

Poříčí 31a, 60300 Brno, Česká republika 